\title{
SELECTRODIALYSIS AND BIPOLAR MEMBRANE ELECTRODIALYSIS COMBINATION FOR INDUSTRIAL PROCESS BRINES TREATMENT: MONOVALENT-DIVALENT IONS SEPARATION AND ACID AND BASE \\ PRODUCTION
}

\author{
Mònica Reig ${ }^{1, *}$, César Valderrama ${ }^{1}$, Oriol Gibert ${ }^{1,2}$, José Luis Cortina ${ }^{1,2}$ \\ ${ }^{1}$ Chemical Engineering Dept., UPC-Barcelona TECH, Av. Diagonal 647, 08028 Barcelona, Spain \\ ${ }^{2}$ CETAQUA Carretera d'Esplugues, 75, 08940 Cornellà de Llobregat, Spain \\ *Corresponding author: Tel.:+34 93 4016997; E-mail address: monica.reig@upc.edu
}

\section{ABSTRACT}

Chemical industries generate large amounts of wastewater rich in different chemical constituents. Amongst these, salts at high concentrations are of major concern, making necessary the treatment of saline effluents before discharge. Because most of these rejected streams comprise a combination of more than one salt at high concentration, it is reasonable to try to separate and revalorize them to promote circular economy at industry site level. For this reason, ion-exchange membranes based technologies were integrated in this study: selectrodialysis (SED) and electrodialysis with bipolar membranes (EDBM). Different process brines composed by $\mathrm{Na}_{2} \mathrm{SO}_{4}$ and $\mathrm{NaCl}$ at different concentrations were treated first by SED to separate each salt, and then by EDBM to produce base $(\mathrm{NaOH})$ and acids $(\mathrm{HCl}$ and $\mathrm{H}_{2} \mathrm{SO}_{4}$ ) from each salt. The optimum of both electrolyte nature and concentration of the SED stack streams was evaluated. Results indicated that it was possible to separate $\mathrm{Cl}^{-}$and $\mathrm{SO}_{4}{ }^{2-}$ depending on the anionic membrane, initial electrolytes and concentrations of each stream. Pure $\mathrm{NaOH}$ and a mixture of $\mathrm{HCl}$ and $\mathrm{H}_{2} \mathrm{SO}_{4}$ with different purities could be obtained. Energy consumption evolutions were plotted and an optimal zone work was found where the consumption values were acceptable.

Keywords: Divalent-monovalent ion fractionation, Acid-base production, Monovalent ion selectivity, High and low concentration, Valorization, Circular economy 


\section{1. INTRODUCTION/BACKGROUND}

2 Process industries (e.g., chemical, metallurgical, mining, petrochemical, food and beverage, etc.) use established wastewater treatments to reduce the organic load by using biological technologies. However, treated waters are still characterized by high total inorganic dissolved solids (sodium chloride $(\mathrm{NaCl})$, sodium sulfate $\left(\mathrm{Na}_{2} \mathrm{SO}_{4}\right)$, calcium chloride $\left(\mathrm{CaCl}_{2}\right)$, sodium nitrate $\left(\mathrm{NaNO}_{3}\right)$, etc. $)$ and direct discharge to the medium is not a disposal option. These brines formed during processing or especially by neutralization of acid/base streams contain high strong electrolytes concentrations and therefore their treatment and disposal routes are limited and new treatment technologies are need. Traditionally, the industrial concentrates are discharged into natural water bodies (with or without dilution depending on the discharge regulations) [1-2] although this method is not environmentally friendly due to the needs to fulfill the higher requirements on water quantities and quality [3]. Then, under the fact that environmental protection and industrial sustainability has become a priority worldwide, considerable efforts have been made to develop new brine management technologies with the aim to avoid or at least minimize any discharge of high salinity streams into the environment when possible.

Brine management reviews [4-6] show that thermal processes (e.g., evaporation and distillation) have been widely researched for water recovery and brine volume reduction. These solutions allow brine volume reduction after water recovery for reuse and generation of a dry salt waste, when a zero liquid discharge (ZLD) scheme is reached, or a wet salt waste, when a ZLD scheme is not achieved. However, the high associated capital expenditures (CAPEX) and operating expenditures (OPEX) of these treatment solutions make them limited $[4,7]$. Moreover, under the new paradigm of circular economy, postulated through, the sustainable process industry resource and energy efficiency (SPIRE) program of the European union industry, resource recovery is the objective to be achieved [8]. Solutions pursued are focused not only on the recovery of water but also on the recovery of the salts present in the brines as pure byproducts. Successful production of pure salts will be achieved only if tailormade separation processes are implemented. Ion exchangers, widely used in industrial applications for decades, accomplish the separation of salts by exhibiting different affinity towards the salts to be separated $[9,10]$. However, for the case of the couple chloride/sulfate most of the anion exchange resins commercialized give 
1 limited possibilities. Alternatively, membrane technologies have become a key separation 2 process when salinity removal is the target objective. Their applications, particularly of reverse osmosis (RO) and nanofiltration (NF), have increased significantly compared to other water treatment technologies. Both are widely used to produce water with low salinity content [11] and to improve the quality of process waters. However, RO use is limited when the objective is the selective recovery of a given target species. In this case, the alternative separation process is directed to the use of schemes where only a given component or group of components are removed specifically. When the selected or target group are charged species (anions and cations) ion-exchange materials and processes as electrodialysis (ED) are the most appropriate options [4]. ED and its related technologies are electrochemical membrane separation processes in which ions are transferred through selective ion-exchange membranes from one solution to another using an electric field as the driving force [12]. Under the influence of an electrical potential difference, the overall result is an enrichment of ions in a concentrate stream and a depletion of ions in a diluate stream. The major application of conventional $\mathrm{ED}$ has historically been concentration of $\mathrm{NaCl}$ from seawater prior to evaporation to produce table salt in Japan for decades [13-16]. Nowadays, ED and RO are competing techniques for the production of potable water from brackish water sources $[12,17]$. In addition, ED is having a growth implementation in bio-based process industries to purify, separate and concentrate byproducts (e.g. whey demineralization [18] and deacidification of fruit juice [19]).

If selective ion separation is the objective, a conventional ED stack presents limitations for ions with the same size and charge sign. However, a new combination of membranes referred to as selectrodialysis (SED) can be used to separate monovalent from divalent ions as it was postulated by Zhang et al. [20]. This membrane configuration has an anionic monovalent membrane between the standard cationic and anionic membranes [21]. Then, once the monovalent and divalent streams have been separated, an ED system including a bipolar membrane (EDBM) between the two standards cationic and anionic can be used to produce acid and base chemicals. A bipolar membrane is formed by an anionic exchange membrane and a cationic one, and when current density is applied in the electrodes, water splitting takes place. Under such arrangement, EDBM is able to produce acid and base from the feed salt due to the water splitting in the bipolar membrane during the EDBM process [22]. EDBM has 
1 shown successful applications, mainly situated in the biotechnology and chemical process 2 industries. The largest potential application includes the recovery of organic acids and bases 3 from salts obtained in synthesis steps, e.g., the recovery of aminoacids, tartaric acid and 4 succinic acid from fermentation broths [23-25], which is accompanied by the production of $5 \mathrm{NaOH}$ as a byproduct, which is in turn recycled to the fermenter to control the $\mathrm{pH}$ of the 6 process. However, the main challenge on EDBM application is the recycling of salt brines as 7 acids and bases to avoid a waste disposal problem. Moreover, the on-site production of 8 chemicals could be economically beneficial as the market prices of the raw materials are 9 gradually increasing.

10 In this study, a mixture of $\mathrm{NaCl}$ and $\mathrm{Na}_{2} \mathrm{SO}_{4}$ have been treated by a combination of $\mathrm{SED}$, to 11 achieve the separation of chloride /sulfate, and EDBM, to produce acid and base from the 12 SED products. A three-compartment configuration has been used to produce acid and base 13 from the feed salt due to the water splitting in the bipolar membrane during the EDBM 14 process.

15

16

17

\section{EXPERIMENTAL}

The proposed valorization scheme (Figure 1) consists in the conversion of residual salty wastewater effluent (rich in $\mathrm{NaCl}$ and $\left.\mathrm{Na}_{\mathrm{S}} \mathrm{SO}_{4}\right)$ into value-added products $\left(\mathrm{HCl}, \mathrm{H}_{2} \mathrm{SO}_{4}\right.$ and $\mathrm{NaOH}$ ) ready to be used in the same industrial plant. The proposed scheme aims thus to fully address the principles of a circular economy by: a) brine minimization, b) reduction of solid wastes production and c) increase of reusability and recyclability of waste through chemical production (acids and bases) for in-plant uses [26,27]. 


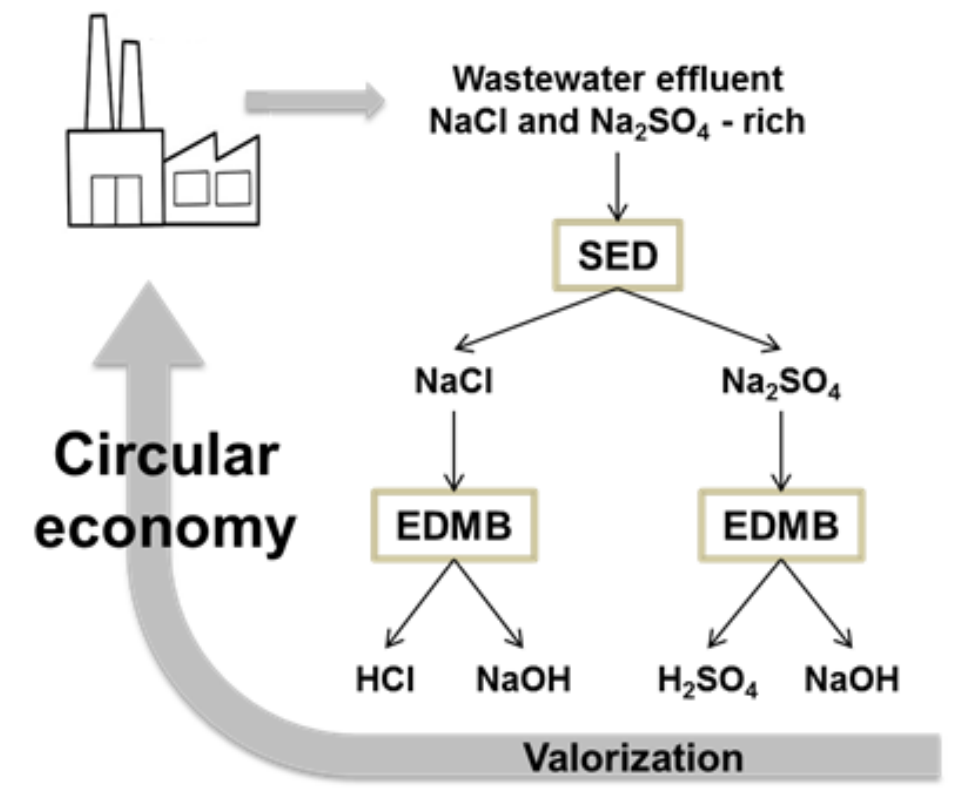

2 Figure 1. Schematic illustration of the wastewater effluent valorization by ED processes

4 Sodium chloride- and sodium sulfate-rich industry process brines were obtained from a

5 chemical company, kept anonymous by a confidentiality agreement. These brines were

6 generated in a dye synthesis step where initially sodium chloride and sodium thiosulfate

7 brines were produced. After a chemical oxidation process using sulfuric solutions, thiosulfate

8 was oxidized to sulfate producing a precipitated elemental S(s) byproduct, which was

9 removed by filtration.

10 Experiments with feed solutions consisting of different concentration wastewater effluents

11 from the chemical company were conducted by a lab-scale SED stack to produce two separate 12 streams ( $\mathrm{NaCl}$-rich stream and $\mathrm{Na}_{2} \mathrm{SO}_{4}$-rich stream) followed by EDBM to produce $\mathrm{HCl}$ and $13 \mathrm{H}_{2} \mathrm{SO}_{4}$ as it is shown in Figure 1.

\subsection{Experimental set-up description and operation}

16 The ED set-up used was a PCCell ED 64-004 (PCCell GmbH, Germany) with a cell of $11 \mathrm{x}$ $1711 \mathrm{~cm}$. The stack consisted of a 4 chambers system with 3 cell triplets with an active 18 membrane area of $64 \mathrm{~cm}^{2}$ per membrane. By means of this equipment it was possible to 19 perform the SED and also the EDBM experiments only by changing the membranes 20 employed in each case. Main characteristics of the membrane as functional group type, 
1 electrical resistance, burst strength and thickness are listed in Table 1.

2

3 Table 1. Main characteristics of the SED and EDBM membrane used

\begin{tabular}{|c|c|c|c|c|}
\hline & \multicolumn{2}{|c|}{$\begin{array}{l}\text { Standard anionic and cationic } \\
\text { membranes (AEM, CEM) }\end{array}$} & \multirow{2}{*}{$\begin{array}{c}\text { Selective } \\
\text { membrane } \\
\text { (MVA) }\end{array}$} & \multirow{2}{*}{$\begin{array}{c}\text { Bipolar } \\
\text { membrane (BP) }\end{array}$} \\
\hline & PC SA & PC SK & & \\
\hline Type & $\begin{array}{l}\text { Strongly alkaline } \\
\text { (ammonium) }\end{array}$ & $\begin{array}{l}\text { Strongly acidic } \\
\text { (sulfonic acid) }\end{array}$ & $\begin{array}{l}\text { Strongly alkaline } \\
\text { (ammonium) }\end{array}$ & \multirow{4}{*}{$\begin{array}{c}\text { Water splitting } \\
\text { efficiency }>95 \% \\
\text { Water splitting } \\
\text { voltage: } 0.8-1 \mathrm{~V}\end{array}$} \\
\hline General use & $\begin{array}{c}\text { Standard } \\
\text { desalination }\end{array}$ & $\begin{array}{c}\text { Standard } \\
\text { desalination }\end{array}$ & $\begin{array}{c}\text { Monovalent } \\
\text { anion selective }\end{array}$ & \\
\hline $\begin{array}{c}\text { Electric resistance } \\
\left(\Omega \mathrm{cm}^{2}\right)\end{array}$ & $\sim 1.8$ & $\sim 2.5$ & $\sim 20$ & \\
\hline $\begin{array}{l}\text { Burst strength } \\
(\mathrm{MPa})\end{array}$ & $0.4-0.5$ & $0.4-0.5$ & 0.2 & \\
\hline $\begin{array}{c}\text { Maximum } \\
\text { operating } \\
\text { temperature }\left({ }^{\circ} \mathrm{C}\right) \\
\end{array}$ & 60 & 50 & 40 & 40 \\
\hline Thickness (mm) & $0.18-0.22$ & $0.16-0.20$ & 0.11 & $0.20-0.35$ \\
\hline
\end{tabular}

The membrane configuration in the SED stack was based on a conventional ED but incorporating one monovalent selective anion exchange membrane (MVA) between a standard anion exchange membrane (AEM) and a standard cation one (CEM). All the membranes were supplied by PCCell. CEM and AEM were regarded as having no selectivity to their counter-ions (they were assumed to be an ideal non-selective CEM and an ideal nonselective AEM, respectively) whereas the MVA had a limited selectivity to monovalent anions, i.e., monovalent anions (e.g., $\mathrm{Cl}^{-}$) have a higher transport number than multivalent anions (e.g., $\mathrm{SO}_{4}{ }^{2-}$ ). The proposed configuration for the $\mathrm{Cl}^{-} / \mathrm{SO}_{4}{ }^{2-}$ separation is shown in Figure 2, the feed and the product streams comprised a $\mathrm{Cl}^{-} / \mathrm{SO}_{4}{ }^{2-}$ mixture with cation $\mathrm{Na}^{+}$. The purpose of such configuration was to enrich $\mathrm{SO}_{4}{ }^{2-}$ while removing $\mathrm{Cl}^{-}$in the product compartment. The MVA was a monovalent selective anion exchange membrane with a selective factor of " $n$ ". Selective factor (n) is a simplified parameter to reflect membrane selectivity, which is calculated by the ion molar amount ratio which two types of ions are transported through the membrane. This MVA-AEM-CEM unit was a repeating membrane trio in the SED stack which had three compartments (denoted as feed, product and brine). By applying an electrical potential, $\mathrm{Cl}^{-}$and $\mathrm{SO}_{4}{ }^{2-}$ anions were attracted to the anode whereas $\mathrm{Na}^{+}$ cations were attracted to the cathode. In the feed compartment, cations were transported 
1 through the CEM membrane to the brine compartment, while anions were transported through

2 the AEM to the product compartment. Since the AEM was an ideal non-selective membrane,

3 the same molar amount (m) of anion $\mathrm{Cl}^{-}$and $\mathrm{SO}_{4}{ }^{2-}$ was transported through the AEM to the

4 product compartment. Meanwhile, due to the electroneutrality in the feed solution, $3 \mathrm{~m}$ of $\mathrm{Na}^{+}$

5 passed through the CEM to the brine compartment. Due to the MVA membrane, only $\mathrm{Cl}^{-}$ions

6 passed through it achieving a $\mathrm{NaCl}$ concentrated stream in the brine compartment and a

$7 \mathrm{Na}_{2} \mathrm{SO}_{4}$ concentrated stream in the product compartment. Then, SED system consisted of 4

8 streams: electrode rinse, salt (diluted), brine (monovalent anions-rich) and product (divalent

9 anions-rich).

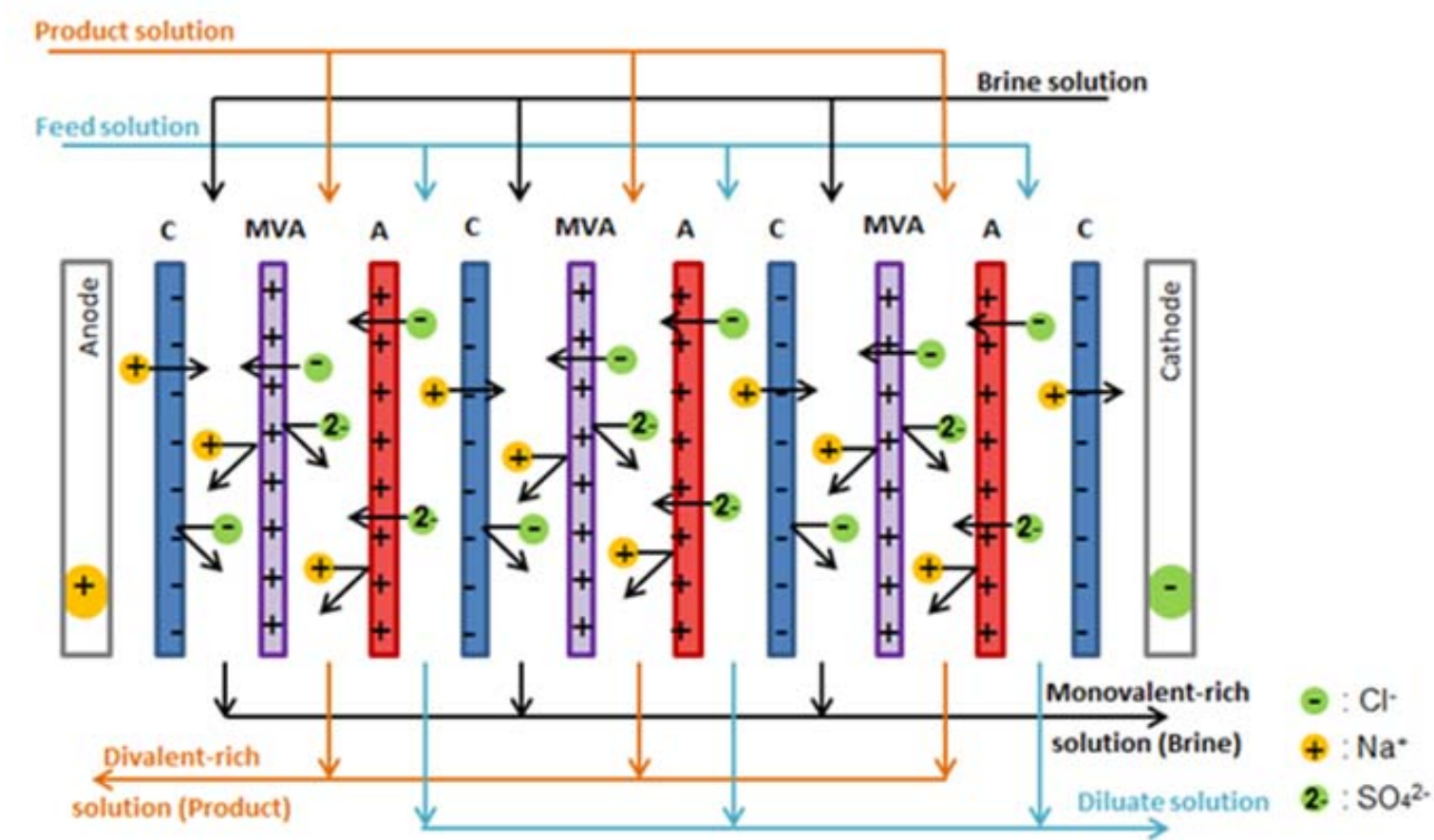

11 Figure 2. Selectrodialysis (SED) stack scheme including membranes arrangement and

12 definition of stacks streams.

14 On the other hand, the EDBM system was also composed by 4 streams: electrode rinse, salt 15 (diluted), acid and base (which increase its concentration). In this case, each cell triplet was 16 composed of one CEM, one AEM and one bipolar membrane (BM). 
1 The set-up scheme for the EDBM and the SED systems operated under a recirculation 2 configuration is shown in Figure 3.

a)
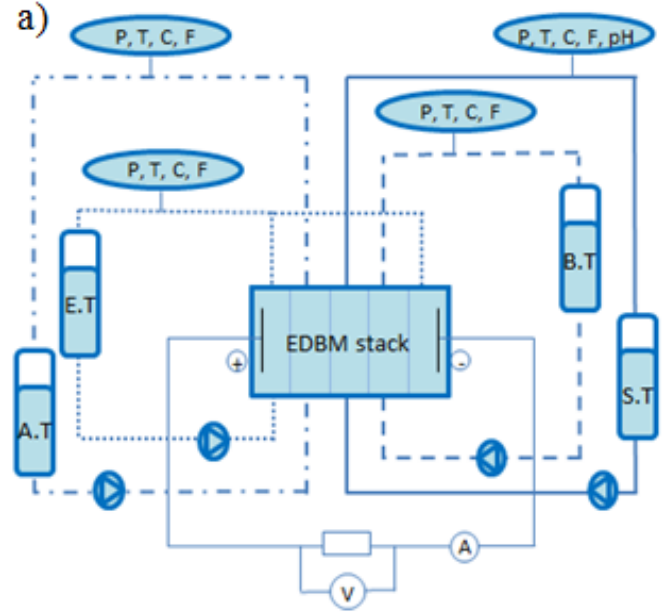

Acid loop
Base loop - - - - - -

Electrode rinse loop b)

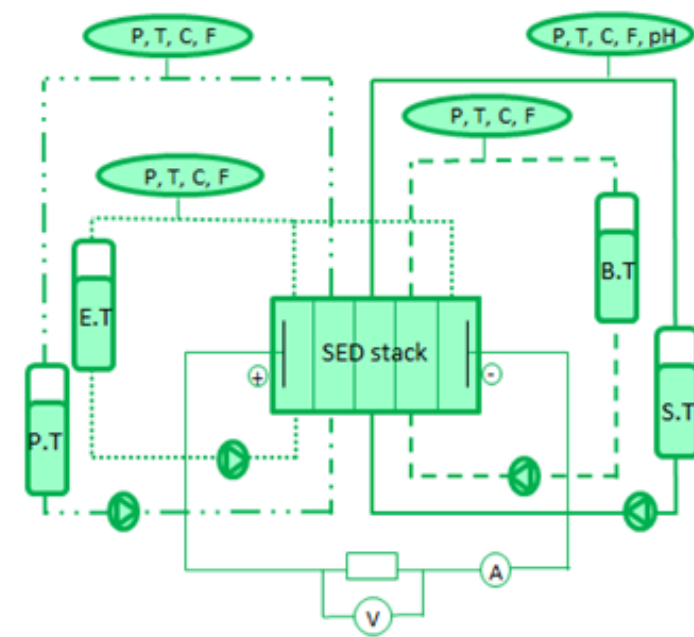

Salt loop

Brine loop

Product loop $\cdots-\cdots-$

Figure 3. Pilot plants scheme a) EDBM configuration and b) SED configuration. (P: pressure sensor, T: temperature sensor, $\mathrm{C}$ : conductivity sensor, $\mathrm{F}$ : flow-meter, $\mathrm{pH}$ : $\mathrm{pH}$-meter, $\mathrm{A}$ : ammeter, V: voltmeter, S.T: salt tank, A.T: acid or product tank, B.T: base tank (EDBM) and brine tank (SED), P.T: product brine, E.T: electrode rinse tank).

The operation of SED and EDBM systems started once electrical current was applied. In order to do not damage the membranes, some initial salt concentration was needed in each tank. For this reason, different initial salts $\left(\mathrm{NaCl}, \mathrm{Na}_{2} \mathrm{SO}_{4}\right.$ or a mixture of both) and concentration levels in each stream were tested to achieve the maximum separation of monovalent and divalent anions by SED under constant voltage conditions of $9 \mathrm{~V}$ and several chemical industrial effluents. Then, both streams obtained by SED (one monovalent-rich and the other divalent-rich salty current) were treated separately by EDBM to obtain the corresponding acid and base products while desalting the feed salt. In the EDBM system, $\mathrm{NaOH}$ was introduced initially in the base tank, but for the acid species, again several acids $\left(\mathrm{HCl}, \mathrm{H}_{2} \mathrm{SO}_{4}\right.$ or a mixture of both) and concentrations of them were tested to achieve a better separation at constant voltage of $9 \mathrm{~V}$. 
1 For both SED and EDBM systems, $1 \mathrm{~L}$ of initial solution was introduced in each tank. All reagents used were of quality analysis (PA-ACS-ISO reagent, PANREAC). For the electrode rinse compartment, $0.42 \mathrm{M} \mathrm{Na}_{2} \mathrm{SO}_{4}$ was used in all the tests. Flow rates were set at $100 \mathrm{~L} / \mathrm{h}$ in the electrode rinse stream and $15-20 \mathrm{~L} / \mathrm{h}$ in the others. As it can be seen in Figure 3, pressure, temperature and conductivity were monitored during the experimentation by means of sensors located in each stream of the ED set-up. Besides, the $\mathrm{pH}$ in the salt stream and the electrical current and voltage for all the system were also monitored. Samples of each tank were taken during the performance until the conductivity in the feed tank was almost zero and then analyzed to know the concentration of each stream.

\subsection{Experimental protocols and methodologies}

Separation of $\mathrm{Cl}^{-} / \mathrm{SO}_{4}{ }^{2-}$ mixtures was carried out by SED. Three feed solution qualities were assessed, namely: low concentrated effluent (with $63 \mathrm{mM} \mathrm{Cl}^{-}$and $26 \mathrm{mM} \mathrm{SO}_{4}{ }^{2-}$ ), medium concentrated effluent (with $151 \mathrm{mM} \mathrm{Cl}^{-}$and $230 \mathrm{mM} \mathrm{SO}_{4}{ }^{2-}$ ) and high concentrated effluent (with $497 \mathrm{mM} \mathrm{Cl}^{-}$and $840 \mathrm{mM} \mathrm{SO}_{4}{ }^{2-}$ ). Process $\mathrm{NaCl} / \mathrm{Na}_{2} \mathrm{SO}_{4}$ brines used in this study were characterized by very low levels of divalent cations e.g., $\mathrm{Mg}(\mathrm{II})$ and $\mathrm{Ca}$ (II) as water used in the synthesis process was demineralized water. Values of both metals were always below 3 $\mathrm{mg} / \mathrm{L}\left(0.075 \mathrm{mM} \mathrm{Ca}^{2+} ; 0.123 \mathrm{mM} \mathrm{Mg}^{2+}\right)$.

For the brine compartment an initial pure $\mathrm{NaCl}$ solution was used, since this compartment it would become the monovalent-rich during the experiment because of the membrane disposal. The product loop was initially filled with a $\mathrm{NaCl}, \mathrm{Na}_{2} \mathrm{SO}_{4}$ or a mixture of both solutions. The product compartment would become the divalent-rich with the experimental time, and due to the membrane disposal the $\mathrm{Cl}^{-}$ions could pass through the MVA and led the compartment without monovalent ions. For this reason, several experiments were carried out to determine the initial salt that offered the best $\mathrm{Cl}^{-} / \mathrm{SO}_{4}{ }^{2-}$ separation (Table 2). Once the optimal initial salt was determined to be pure $\mathrm{NaCl}$, more experiments were carried out to determine its optimal concentration to achieve the maximum monovalent/divalent anions separation. In this case, the initial brine and product streams concentration were varied. Table 2 collects the experimental design for the SED tests for both, product electrolyte and composition selection. 
1 Table 2. Experimental concentrations used for $\mathrm{Cl}^{-} / \mathrm{SO}_{4}{ }^{2-}$ separation by $\mathrm{SED}$ configuration

\begin{tabular}{|c|c|c|c|}
\hline & Feed & Brine & Product \\
\hline \multirow{3}{*}{$\begin{array}{l}\text { Product electrolyte selection } \\
\text { (low concentration) }\end{array}$} & \multirow{3}{*}{$\begin{array}{c}63 \mathrm{mM} \mathrm{Cl}^{-} \\
26 \mathrm{mM} \mathrm{SO}_{4}^{2-}\end{array}$} & $31 \mathrm{mM} \mathrm{Cl}^{-}$ & $31 \mathrm{mM} \mathrm{Cl}^{-}$ \\
\hline & & $31 \mathrm{mM} \mathrm{Cl}^{-}$ & $13 \mathrm{mM} \mathrm{SO}_{4}{ }^{2-}$ \\
\hline & & $31 \mathrm{mM} \mathrm{Cl}^{-}$ & $\begin{array}{l}15 \mathrm{mM} \mathrm{Cl}^{-} \\
6 \mathrm{mM} \mathrm{SO}_{4}^{2-}\end{array}$ \\
\hline \multirow{3}{*}{$\begin{array}{l}\text { Product electrolyte selection } \\
\text { (medium concentration) }\end{array}$} & \multirow{3}{*}{$\begin{array}{c}151 \mathrm{mM} \mathrm{Cl}^{-} \\
230 \mathrm{mM} \mathrm{SO}_{4}^{2-}\end{array}$} & $76 \mathrm{mM} \mathrm{Cl}^{-}$ & $76 \mathrm{mM} \mathrm{Cl}^{-}$ \\
\hline & & $76 \mathrm{mM} \mathrm{Cl}^{-}$ & $115 \mathrm{mM} \mathrm{SO}_{4}{ }^{2}$ \\
\hline & & $76.0 \mathrm{mM} \mathrm{Cl}^{-}$ & $\begin{array}{c}38 \mathrm{mM} \mathrm{Cl}^{-} \\
58 \mathrm{mM} \mathrm{SO}_{4}^{2-}\end{array}$ \\
\hline \multirow{3}{*}{$\begin{array}{l}\text { Product composition } \\
\text { selection } \\
\text { (medium concentration) }\end{array}$} & \multirow{3}{*}{$\begin{array}{c}151 \mathrm{mM} \mathrm{Cl}^{-} \\
230 \mathrm{mM} \mathrm{SO}_{4}^{2-}\end{array}$} & $76 \mathrm{mM} \mathrm{Cl}^{-}$ & $76 \mathrm{mM} \mathrm{Cl}^{-}$ \\
\hline & & $151 \mathrm{mM} \mathrm{Cl}^{-}$ & $151 \mathrm{mM} \mathrm{Cl}^{-}$ \\
\hline & & $302 \mathrm{mM} \mathrm{Cl}^{-}$ & $302 \mathrm{mM} \mathrm{Cl}^{-}$ \\
\hline \multirow{2}{*}{$\begin{array}{l}\text { Product composition } \\
\text { selection } \\
\text { (high concentration) }\end{array}$} & \multirow{2}{*}{$\begin{array}{c}497 \mathrm{mM} \mathrm{Cl}^{-} \\
840 \mathrm{mM} \mathrm{SO}_{4}{ }^{2-}\end{array}$} & $497 \mathrm{mM} \mathrm{Cl}^{-}$ & $497 \mathrm{mM} \mathrm{Cl}^{-}$ \\
\hline & & $995 \mathrm{mM} \mathrm{Cl}^{-}$ & $995 \mathrm{mM} \mathrm{Cl}^{-}$ \\
\hline
\end{tabular}

3 Production of acid and base solutions was carried out by EDBM. Once the SED experiments 4 were done, two separate streams were obtained: a NaCl-rich solution in the brine stream and a $5 \mathrm{Na}_{2} \mathrm{SO}_{4}$-rich solution in the product stream. These two streams were treated separately by 6 EDBM. However, firstly the acid selection between $\mathrm{HCl}, \mathrm{H}_{2} \mathrm{SO}_{4}$ or a mixture of both in the 
1 acid compartment was carried out using the low concentration feed solution (Table 3).

2 Secondly, once the optimal option was determined, the EDBM experiments with the two SED

3 solutions (monovalent-rich and divalent-rich) obtained were conducted. In all the EDBM

4 tests, $\mathrm{NaOH}$ was used as initial base, since the main cation in all streams was $\mathrm{Na}^{+}$. Table 3

5 summarizes the experimental concentrations for each EDBM experiment.

6

7 Table 3. Experimental concentrations used for acid and base solutions production by EDMB 8 configuration.

9

\begin{tabular}{|c|c|c|c|}
\hline & Feed & Base & Acid \\
\hline \multirow{3}{*}{$\begin{array}{c}\text { Acid selection } \\
\text { (low concentration) }\end{array}$} & \multirow{3}{*}{$\begin{array}{c}63 \mathrm{mM} \mathrm{Cl}^{-} \\
26 \mathrm{mM} \mathrm{SO}_{4}{ }^{2-}\end{array}$} & \multirow{3}{*}{$50 \mathrm{mM} \mathrm{NaOH}$} & $50 \mathrm{mM} \mathrm{HCl}$ \\
\hline & & & $50 \mathrm{mM} \mathrm{H}_{2} \mathrm{SO}_{4}$ \\
\hline & & & $\begin{array}{c}25 \mathrm{mM} \mathrm{HCl}^{2} \\
25 \mathrm{mM} \mathrm{H}_{2} \mathrm{SO}_{4}\end{array}$ \\
\hline \multirow{2}{*}{ Experiments from SED } & $1477 \mathrm{mM} \mathrm{Cl}^{-}$ & $100 \mathrm{mM} \mathrm{NaOH}$ & $100 \mathrm{mM} \mathrm{HCl}$ \\
\hline & $485 \mathrm{mM} \mathrm{SO}_{4}{ }^{2-}$ & $100 \mathrm{mM} \mathrm{NaOH}$ & $10100 \mathrm{mM} \mathrm{H}_{2} \mathrm{SO}_{4}$ \\
\hline
\end{tabular}

\subsection{Analytical methodologies and chemical analysis}

Ion chromatography (Dionex ICS-1000 and ICS-1100) was used to quantify the ion concentration on each stream $\left(\mathrm{Na}^{+}, \mathrm{Cl}^{-}\right.$and $\left.\mathrm{SO}_{4}{ }^{2-}\right)$. Besides, it was possible to determine the calcium and magnesium concentration by atomic absorption (Varian, SpectrAA-640). Finally, automatic acid-base titration system (Titration Excellence T-70) was employed to determine the $\mathrm{HCl}, \mathrm{H}_{2} \mathrm{SO}_{4}$ and $\mathrm{NaOH}$ concentrations.

\subsection{Evaluation of the monovalent/divalent anion separation and energy consumption}

The purity of each anion was calculated according to Equation 1 and thus the selectivity and the separation efficiency between two anions $a$ and $b$ for the MVA membrane were assessed:

$$
P_{a}=\frac{\left(C a_{t}-C a_{i}\right)}{\left(C a_{t}-C a_{i}\right)+\left(C b_{t}-C b_{i}\right)} \cdot 100 \quad \text { Equation } 1
$$

Where $\mathrm{C}$ denotes the concentration of each ion $(\mathrm{M})$ at time " $t$ " or at initial time " $i$ ". According to this estimation, the purity value ranges between 0 and 100 , values close to 100 meaning a 
1 high retention of ion $b$ ion in the diluate side and a high selectivity of ion $a$; and values close 2 to zero meaning the opposite case [28].

3 For the SED experiments, the purity was calculated as the percentage of each ion in the 4 product and brine streams. For the EDBM tests, Equation 1 was used to determine the anions 5 behavior in the acid compartment to obtain the maximum separation. The separation of both 6 anions $\left(\mathrm{Cl}^{-}\right.$and $\left.\mathrm{SO}_{4}{ }^{2-}\right)$, the MVA membrane efficiency, the quality of the solutions produced 7 and the separation in the feed stream for both ED systems were evaluated by using the purity 8 value.

9 Another important parameter to determine was the energy consumption (Ec) in the ED stack, and it was calculated by means of Equation 2.

$$
\operatorname{Ec}\left(\frac{k W h}{k g \text { product }}\right)=\frac{(\mathrm{U} \cdot \mathrm{I} \cdot \mathrm{t}) / 1000}{\mathrm{~m}_{\text {final product }}}
$$

Equation 2

11 Where U (V) and I (A) are the voltage and current applied in the ED stack, respectively, $\mathrm{t}(\mathrm{h})$ 12 is the operation time of the operation and $\mathrm{m}_{\text {final product }}(\mathrm{kg})$ is the mass obtained of the desired 13 product $\left(\mathrm{NaCl}\right.$ and $\mathrm{Na}_{2} \mathrm{SO}_{4}$ concentrate solutions achieved in the SED study or the acid and 14 base produced by EDBM).

\section{RESULTS}

Conductivity values measured during the tests were used to confirm that both systems were working as expected. The conductivity of the electrode rinse stream remained constant during each experiment, since there was not any interaction with the others streams. Indeed, the conductivity in the feed solution decreased with time as ions migrated to the brine or product compartments once SED was put in operation or to the base and acid compartments when EDBM was employed. For these last two streams (brine/base and product/acid), the conductivity evolution was different depending on whether SED or EDBM was used. For the SED experiments, the concentration of $\mathrm{NaCl}$ in the brine stream increased due to the transport of both $\mathrm{Cl}^{-}$through the MVA membrane and $\mathrm{Na}^{+}$through the CEM from the feed solution to this compartment. The $\mathrm{Na}_{2} \mathrm{SO}_{4}$-rich product stream kept almost constant its concentration, as both $\mathrm{Cl}^{-}$and $\mathrm{SO}_{4}{ }^{2-}$ anions crossed the $\mathrm{AEM}$ from the feed solution, but $\mathrm{Cl}^{-}$leaved this compartment through the MVA. For the EDBM system, acid and base streams increased its 
1 conductivity, due to the water splitting produced in the BP membrane and the CEM and the

2 AEM disposal in the stack.

3

$4 \quad 3.1$ Chloride/sulfate separation by SED configuration

5 On the basis of the process stream composition (e.g., concentration values of both 6 electrolytes), four sets of experiments were carried out in order to find the optimal electrolyte 7 composition to be introduced in the product stream, and then its optimal initial concentration 8 that provides the highest $\mathrm{Cl}^{-} / \mathrm{SO}_{4}{ }^{2-}$ separation factors. First, $\mathrm{NaCl}, \mathrm{Na}_{2} \mathrm{SO}_{4}$ and a mixture of 9 both solutions were tested by using electrolyte streams in the low $\left(63 \mathrm{mM} \mathrm{Cl}^{-}\right.$and $26 \mathrm{mM}$ $\left.10 \mathrm{SO}_{4}{ }^{2-}\right)$ and medium concentration range $\left(151 \mathrm{mM} \mathrm{Cl}^{-}\right.$and $\left.230 \mathrm{mM} \mathrm{SO}_{4}{ }^{2-}\right)$.

11 Table 4 collects the final $\mathrm{Cl}^{-}$and $\mathrm{SO}_{4}{ }^{2-}$ concentrations in the brine compartment and the 12 electrolyte purity reached (Equation 1) with the low concentration effluent $\left(26 \mathrm{mM} \mathrm{Cl}^{-}\right.$and 63 $\left.13 \mathrm{mM} \mathrm{SO}_{4}{ }^{2-}\right)$ when using different initial salts in the product tank and $\mathrm{NaCl}\left(31 \mathrm{mM} \mathrm{Cl}^{-}\right)$in the 14 brine tank.

15

16 Table 4. Brine composition and separation percentage obtained in each SED experiment

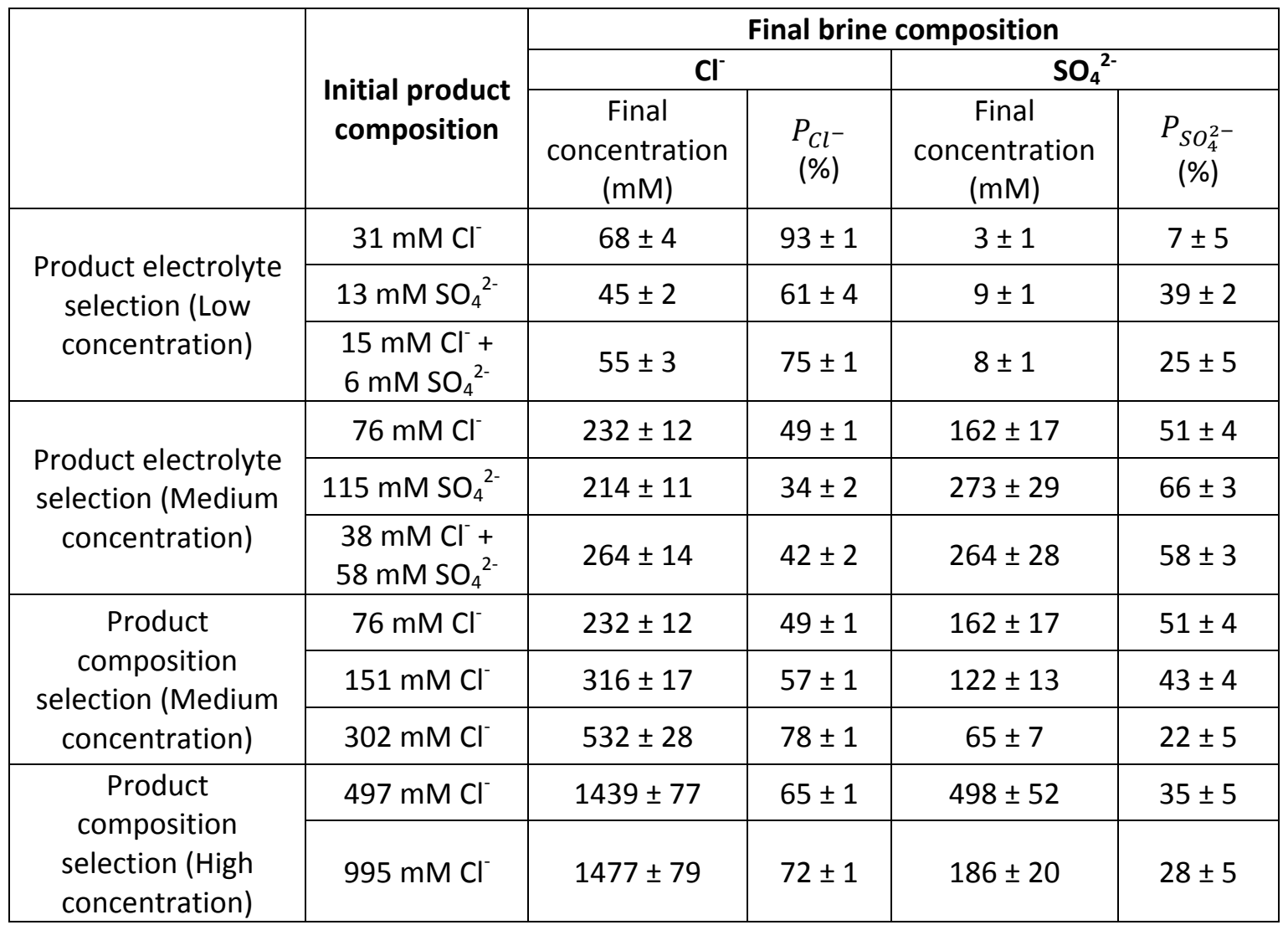


1 The objective was to obtain a brine stream as pure in $\mathrm{NaCl}$ as possible after the $\mathrm{SED}$ trials. As can be seen in Table 4, by using only $\mathrm{NaCl}$ as initial product it was possible to achieve a $93 \%$ purity of $\mathrm{Cl}^{-}$in the brine compartment when low concentration feed solution was used. Lower $\mathrm{Cl}^{-}$purity values $\left(61\right.$ and $75 \%$ ) were reached only if $\mathrm{Na}_{2} \mathrm{SO}_{4}$ or a mixture of both salts $(\mathrm{NaCl}$ and $\mathrm{Na}_{2} \mathrm{SO}_{4}$ ) were initially used as product solutions, thus obtaining lower anions separations than the one achieved when using $\mathrm{NaCl}$ as initial product. Moreover, similar trials were carried out again, but in this case by using brine with a medium initial concentration $\left(151 \mathrm{mM} \mathrm{Cl}^{-}\right.$and $\left.230 \mathrm{mM} \mathrm{SO}_{4}{ }^{2-}\right)$. Then, the initial brine composition was $76 \mathrm{mM} \mathrm{Cl}^{-}$, while varying the initial salt solution $\left(\mathrm{NaCl}, \mathrm{Na}_{2} \mathrm{SO}_{4}\right.$ and a mixture of both) in the product tank. Table 4 also lists the results of these tests. In this second set of experiments, separation was not achieved in either case. Purity values between 34 and $49 \%$ were obtained for both streams for $\mathrm{Cl}^{-}$and $\mathrm{SO}_{4}{ }^{2-}$, which are clearly lower than those achieved with the first set of experiments at lower concentrations. In both cases, the optimal option was using $\mathrm{NaCl}$ as a single salt solution in the product compartment. For this reason, $\mathrm{NaCl}$ solutions of different concentrations were used as initial product stream in the third set of experiments. Again, different process brines (medium and high concentration) were used. Table 4 shows the results in the case of using $151 \mathrm{mM} \mathrm{Cl}^{-}$and $230 \mathrm{mM} \mathrm{SO}_{4}{ }^{2-}$ as initial (medium) concentration feed. In this case, the higher the initial $\mathrm{NaCl}$ concentration introduced in the product and brine tanks the higher the purities obtained, with purities values reaching almost $80 \% \mathrm{Cl}^{-} / 20 \% \mathrm{SO}_{4}{ }^{2-}$ when using the double of the initial $\mathrm{NaCl}$ concentration $\left(302 \mathrm{mM} \mathrm{Cl}^{-}\right)$.

Experiments were repeated with a higher concentrated brine stream $\left(497 \mathrm{mM} \mathrm{Cl}^{-}\right.$and $840 \mathrm{mM}$ $\mathrm{SO}_{4}{ }^{2-}$ ) as feed solution. Again, almost $80 \% \mathrm{Cl}^{-} / 20 \% \mathrm{SO}_{4}{ }^{2-}$ was separated when working with the highest initial product and brine $\mathrm{NaCl}$ concentration (Table 4).

For all the experiments commented above, $\mathrm{Cl}^{-}$and $\mathrm{SO}_{4}{ }^{2-}$ contents in the product stream were analyzed. As an average, $90.5 \% \mathrm{SO}_{4}{ }^{2-}$ and $9.5 \% \mathrm{Cl}^{-}$were calculated as final purity of each ion in the product stream. In comparison with the literature reviewed, Zhang et al. [20] reached similar $\mathrm{SO}_{4}{ }^{2-}$ purity values in the product stream (over $85 \%$ ) working with a SED system to separate $\mathrm{Cl}^{-}$and $\mathrm{SO}_{4}{ }^{2-}$ and using monovalent selective (PC MVA) and non-selective membranes (PC SK and PC SA) from PCCell GmbH, Germany. Moreover, Tanaka et al. [29] also studied the $\mathrm{Cl}^{-}$and $\mathrm{SO}_{4}{ }^{2-}$ separation and values around $86 \% \mathrm{SO}_{4}{ }^{2-}$ and $14 \% \mathrm{Cl}^{-}$were 
1 reported using a conventional configuration of ED where only selective monovalent ion exchange resins Aciplex K172 and A172 (Asahi Chemical Co., Japan) were used .

3 Finally, it can be concluded that the optimal option to obtain the higher $\mathrm{Cl}^{-} / \mathrm{SO}_{4}{ }^{2-}$ by means of SED was using the higher initial $\mathrm{NaCl}$ brine and product concentration, in this case the double than in the initial feed stream. The reason of this behavior relies on the diffusion phenomena. Working with divalent anions, the concentration gradient in both MVA membrane sides was high, so a decrease of their selectivity was observed and, consequently, the migration of the divalent anions. If some initial $\mathrm{SO}_{4}{ }^{2-}$ concentration was introduced in the product tank a concentration gradient could appear and divalent diffusion through the MVA membrane could happen. On the other hand, when $\mathrm{NaCl}$ was introduced in the product compartment, the diffusion contribution diminished due to the decrease of the concentration gradient in both MVA membrane sides, which delimited the product and brine compartments. Increasing the initial chloride concentration in both streams, hindered the diffusion of sulfate ions through the MVA membrane, which represents a better selectivity and also that a reduced fraction of divalent ions could be transported through it.

\subsection{Production of acid and base solutions by EDBM configuration.}

Before using the real product and brine obtained by SED, it was necessary to perform some test in order to study, which was the optimal initial base and acid concentrations. Different initial acid combinations were used $\left(\mathrm{HCl}, \mathrm{H}_{2} \mathrm{SO}_{4}\right.$ or a mixture of both). The least concentrated brine $\left(63 \mathrm{mM} \mathrm{Cl}^{-}\right.$and $\left.26 \mathrm{mM} \mathrm{SO}_{4}{ }^{2-}\right)$ was used as feed solution in this first set of EDBM experiments. Indeed, a mixture of both acids was produced in the acid stream, since the initial feed stream contained both anions, but an $\mathrm{HCl}$-rich solution was the desired product in the acid compartment. The results indicated that $83 \% \mathrm{Cl}^{-} / 17 \% \mathrm{SO}_{4}{ }^{2-}$ separation was obtained when using a pure initial $\mathrm{HCl}$ stream in the acid compartment, against $45 \% \mathrm{Cl}^{-} / 55 \% \mathrm{SO}_{4}{ }^{2-}$ when using pure $\mathrm{H}_{2} \mathrm{SO}_{4}$ or $55 \% \mathrm{Cl}^{-} / 45 \% \mathrm{SO}_{4}{ }^{2-}$ when a mixture of both acids was employed.

28 Figure 4 shows the results when only $\mathrm{HCl}$ was used in the acid compartment, which was the option that yielded the highest $\mathrm{HCl}$ purity. 

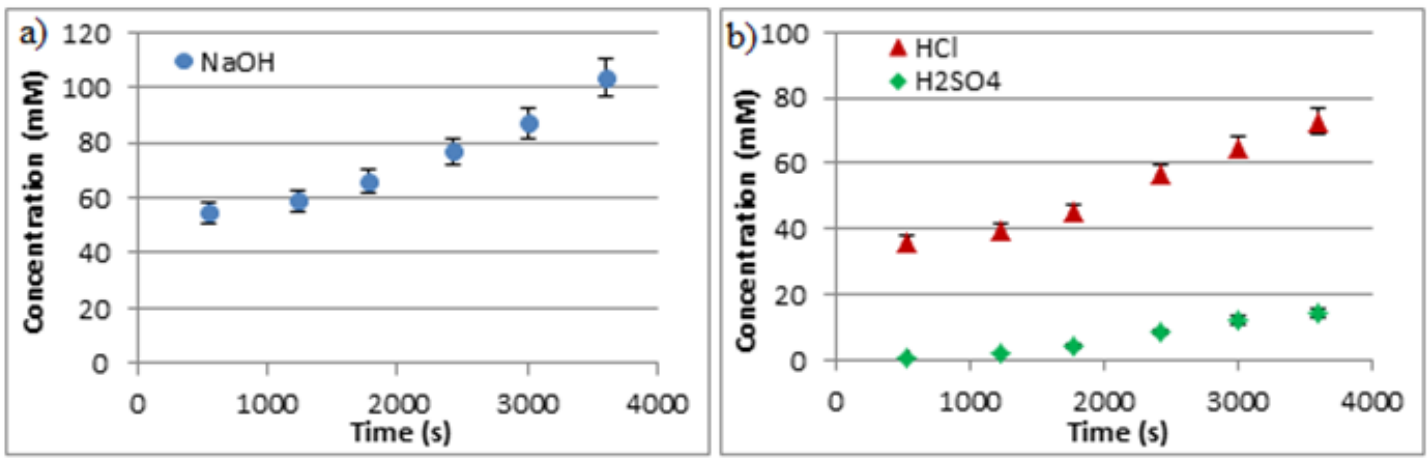

Figure 4. EDBM experiments using $50 \mathrm{mM} \mathrm{HCl}$ as initial acid concentration.

3

4 It is observed in Figure 4 that $\mathrm{NaOH}$ solution doubled its concentration during the 5 experiments from $0.05 \mathrm{M}$ to $0.10 \mathrm{M}$. An $\mathrm{HCl}$-rich acid was produced in the acid compartment, in which $\mathrm{HCl}$ concentration increased from less than $0.05 \mathrm{M}$ to above $0.07 \mathrm{M}$ and final $\mathrm{H}_{2} \mathrm{SO}_{4}$ concentration was lower than $0.02 \mathrm{M}$.

It can be pointed out that it was better to use initial $\mathrm{HCl}$ if higher $\mathrm{HCl}$ acid purity was needed, while for a more concentrated $\mathrm{H}_{2} \mathrm{SO}_{4}$, initial $\mathrm{H}_{2} \mathrm{SO}_{4}$ is required.

Then, for the next set of EDBM experiments, $\mathrm{HCl}$ was used as initial acid solution when the SED monovalent-rich stream was treated and a pure $\mathrm{H}_{2} \mathrm{SO}_{4}$ acid was needed if treating the divalent-rich solution produced by SED. In both cases, $\mathrm{NaOH}$ was concentrated in the base compartment.

EDBM experiments were carried out with the SED brine and product streams obtained working with the higher concentration effluent as SED feed solution and higher product and brine initial concentration (Table 4). The SED monovalent-rich stream had $1477 \mathrm{mM} \mathrm{Cl}^{-}$, but also $186 \mathrm{mM} \mathrm{SO}_{4}{ }^{2-}$, which was used as initial feed for the second set of EDBM experiments. Then, $0.1 \mathrm{M} \mathrm{HCl}$ and $0.1 \mathrm{M} \mathrm{NaOH}$ solutions were initially placed in the acid and base tanks, respectively. Figure 5a shows the concentration evolution for $\mathrm{NaOH}$ in the base stream and also for $\mathrm{HCl}$ and $\mathrm{H}_{2} \mathrm{SO}_{4}$ in the acid compartment. On the other hand, the divalent-rich stream from SED was also used as feed solution for the EDBM system. The solution concentration was $485 \mathrm{mM} \mathrm{SO}_{4}{ }^{2-}$, but also $14 \mathrm{mM} \mathrm{Cl}^{-}$, which was used as initial feed for the tjirdf set of EDBM experiments. In this case, pure $0.1 \mathrm{M} \mathrm{NaOH}$ was used again as initial base, and pure $40.1 \mathrm{M} \mathrm{H}_{2} \mathrm{SO}_{4}$ was employed for the initial acid, instead of $\mathrm{HCl}$, because the major anion in the 
1 feed stream was $\mathrm{SO}_{4}{ }^{2-}$. The concentration evolutions for the $\mathrm{NaOH}$ in the base stream and also

2 for the $\mathrm{H}_{2} \mathrm{SO}_{4}$ and $\mathrm{HCl}$ in the acid compartment are also plotted in Figure $5 \mathrm{~b}$.

3

4
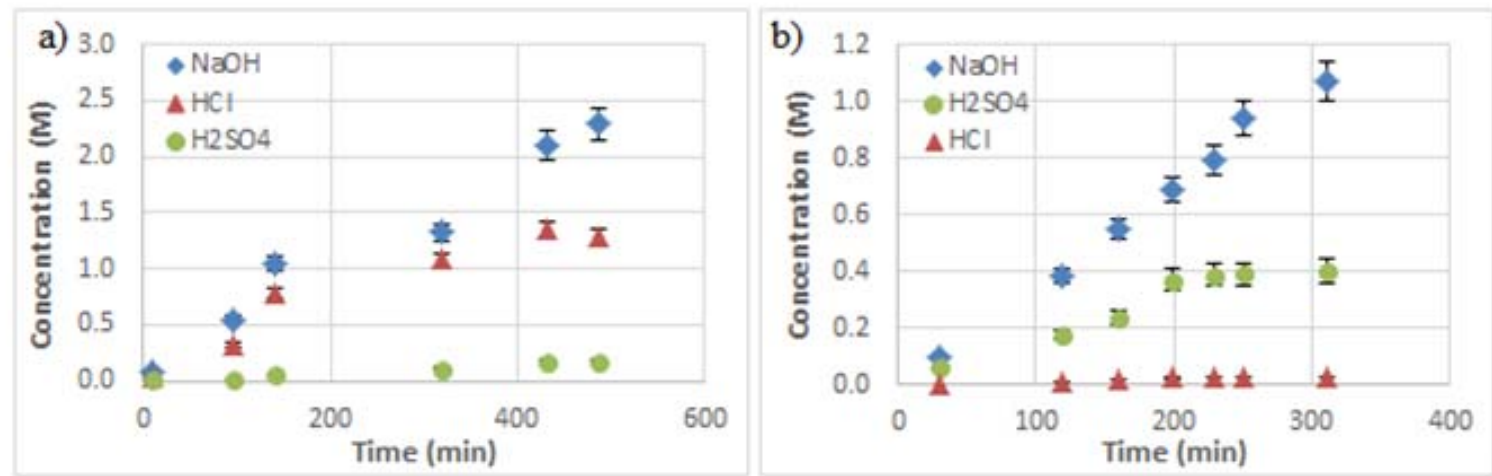

Figure 5. Concentration evolution using as EDBM feed solution the a) SED $\mathrm{Cl}^{-}$-rich stream b) $\mathrm{SED} \mathrm{SO}_{4}{ }^{2-}$-rich stream.

As shown in Figure 5, in both cases it was possible to obtain pure $\mathrm{NaOH}$ in the basic compartment, since the only cation of the initial solution was $\mathrm{Na}^{+}$. By using either the monovalent-rich stream or the divalent-rich one, it was possible to obtain almost pure $\mathrm{HCl}$ or $\mathrm{H}_{2} \mathrm{SO}_{4}$ acid, respectively.

When using the $\mathrm{Cl}^{-}$-rich stream from SED, it was possible to obtain a pure $2.3 \mathrm{M} \mathrm{NaOH}$ in the base compartment, but a mixture of $1.3 \mathrm{M} \mathrm{HCl}$ and $0.2 \mathrm{M} \mathrm{H}_{2} \mathrm{SO}_{4}$ was produced in the acid one. Although a mixture of acids was achieved in the corresponded compartment, $\mathrm{HCl}$ was the prevailing acid with $87 \% \mathrm{Cl}^{-} / 13 \% \mathrm{SO}_{4}{ }^{2-}$ purity.

On the other hand, when the $\mathrm{SO}_{4}{ }^{2-}$-rich stream produced by $\mathrm{SED}$ was introduced in the EDBM system, less concentrated pure $\mathrm{NaOH}(1.1 \mathrm{M})$ and also an almost pure $0.4 \mathrm{M} \mathrm{H}_{2} \mathrm{SO}_{4}$ (with $0.03 \mathrm{M} \mathrm{HCl}$ traces) were obtained.

For this reason, it can be said that it was possible to valorize a non-desirable salty $\mathrm{NaCl}$ and $\mathrm{Na}_{2} \mathrm{SO}_{4}$ solution by means of their separation and concentration into a monovalent and a divalent rich solutions. Each stream could then be treated by EDBM to produce a $\mathrm{NaOH}$ base solution and a $\mathrm{HCl}$-rich or a $\mathrm{H}_{2} \mathrm{SO}_{4}$-rich solution in the acid compartment. Both base and acid solutions could be reused in the same chemical industry to promote circular economy or be sold in the chemical market [27]. 


\section{$1 \quad 3.3$ Energy consumption}

2 Because both systems are electrical current-driven processes, energy consumption (Ec) was a

3 crucial parameter in order to decide their applicability at the industrial scale. Equation 2 was

4 used to calculate Ec in each experiment. The final mass product on Equation 2 was calculated

5 in a different way depending on the membrane configuration SED or EDBM and the desired

6 product.

7 For the SED trials, two desired products were obtained: the $\mathrm{NaCl}$ produced in the brine

8 compartment and the $\mathrm{Na}_{2} \mathrm{SO}_{4}$ solution obtained in the product compartment. Then, both masses were taken into account considering also the initial solutions introduced in each compartment.

11 For the EDBM trials, two products were obtained: acid and base. However, as it was seen in

12 Figure 5, a mixture of $\mathrm{HCl}$ and $\mathrm{H}_{2} \mathrm{SO}_{4}$ was achieved in the acid compartment in every EDBM 13 experiment, although pure $\mathrm{NaOH}$ was produced in the base tank. In the chemical market, the $14 \mathrm{NaOH}$ price is higher than for $\mathrm{HCl}$ or $\mathrm{H}_{2} \mathrm{SO}_{4}$, and therefore this pure $\mathrm{NaOH}$ can be easily 15 commercialized in the industry. For this reason, the $\mathrm{NaOH}$ produced was the final mass product used in Equation 2. Ec evolution curves obtained for SED and for EDBM systems were similar. Figure 6 shows the EC evolution curves for the SED experiments. Each graph represents the three main selections carried out to determine the optimal initial salt in the product tank and its composition: a) electrolyte selection $\left(\mathrm{Cl}^{-}, \mathrm{SO}_{4}{ }^{2-}\right.$ or a mixture of both anions) with the medium feed concentration brine, b) composition selection (with the same or the double feed concentration) with the medium feed concentration brine and c) composition selection (with the same or the double feed concentration) with the high feed concentration brine. 

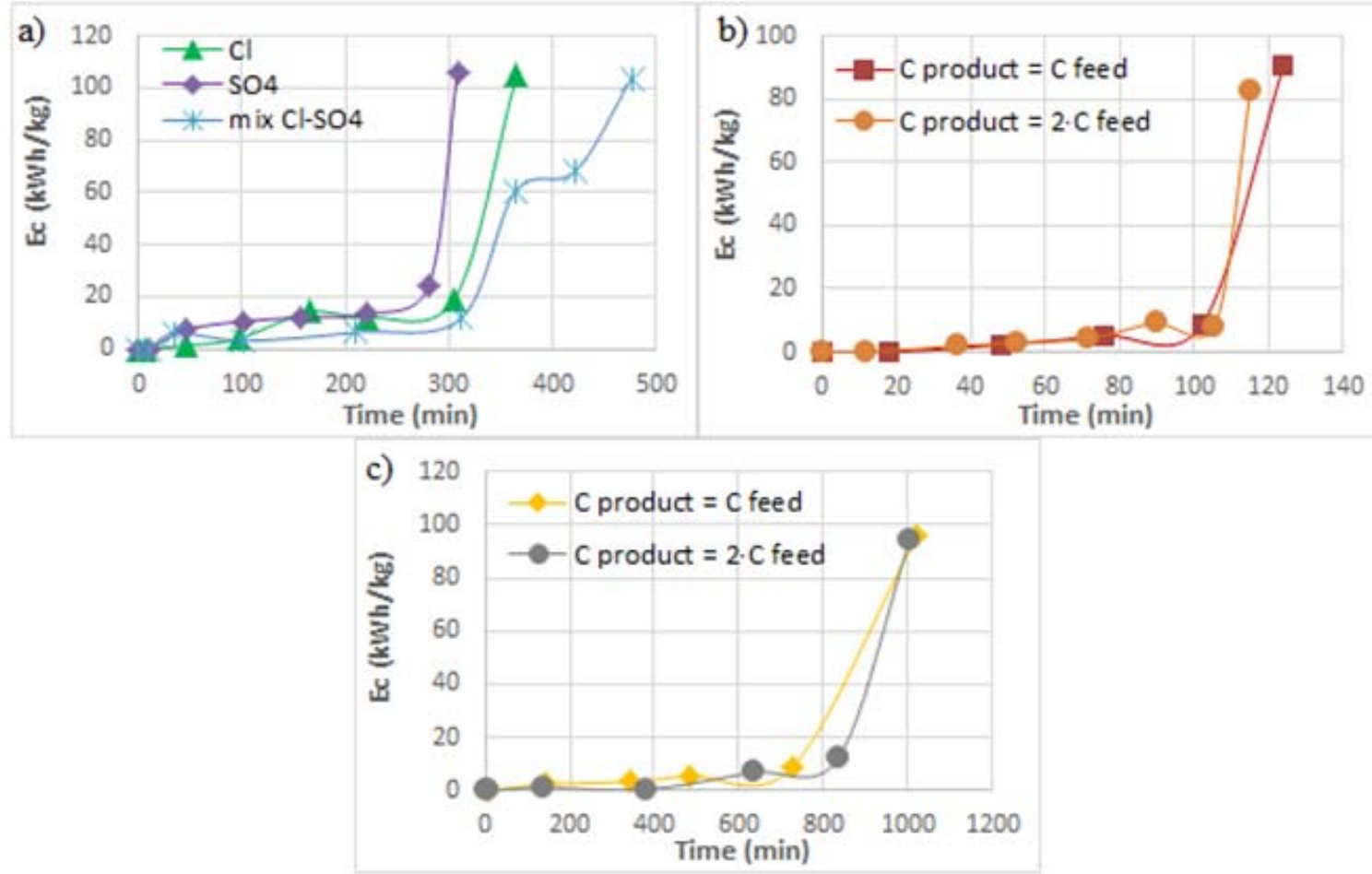

2 Figure 6. SED energy consumption evolution for product selection of a) electrolyte with 3 medium feed concentration, b) composition at medium feed concentration and c) composition 4 at high feed concentration.

5

6 As it is observed in Figure 6, firstly, a slightly constant Ec value was obtained until the brine 7 and product production achieved a steady value, then the Ec increased drastically. This increase was due to osmosis and ion diffusion fluxes inside the SED stack reach a maximum because of the concentration gradient between the diluate and the concentrated compartments. Once the concentration of brine and product increased really slowly, the energy applied is used to slowly increase their concentrations and then, Ec increases. It can be concluded that it is important to work in the optimal zone to maintain low Ec values. This Ec behavior was reported elsewhere $[29,30]$. Table 5 reports the Ec experimental values, taken into account the optimal zone work for each experiment. 
1 Table 5.Compilation of electrical consumption values $(\mathrm{Ec})$ values at the optimal zone work

2 for the SED and EDBM experiments.

\begin{tabular}{|c|c|c|c|}
\hline ED system & & $\begin{array}{l}\text { Initial product } \\
\text { composition }\end{array}$ & $\begin{array}{l}\text { Energy consumption } \\
\text { (kWh/kg product) }\end{array}$ \\
\hline \multirow{11}{*}{ SED } & \multirow{3}{*}{$\begin{array}{l}\text { Product electrolyte } \\
\text { selection } \\
\text { (Low concentration) }\end{array}$} & $31 \mathrm{mM} \mathrm{Cl}^{-}$ & 0.35 \\
\hline & & $13 \mathrm{mM} \mathrm{SO}_{4}{ }^{2-}$ & 0.97 \\
\hline & & $15 \mathrm{mM} \mathrm{Cl}^{-}+6 \mathrm{mM} \mathrm{SO}_{4}{ }^{2-}$ & 0.47 \\
\hline & \multirow{3}{*}{$\begin{array}{c}\text { Product electrolyte } \\
\text { selection } \\
\text { (Medium concentration) }\end{array}$} & $76 \mathrm{mM} \mathrm{Cl}^{-}$ & 7.9 \\
\hline & & $115 \mathrm{mM} \mathrm{SO}_{4}{ }^{2-}$ & 8.9 \\
\hline & & $38 \mathrm{mM} \mathrm{Cl}^{-}+58 \mathrm{mM} \mathrm{SO}_{4}^{2-}$ & 7.1 \\
\hline & \multirow{3}{*}{$\begin{array}{l}\text { Product composition } \\
\text { selection } \\
\text { (Medium concentration) }\end{array}$} & $76 \mathrm{mM} \mathrm{Cl}^{-}$ & 7.9 \\
\hline & & $151 \mathrm{mM} \mathrm{Cl}^{-}$ & 5.4 \\
\hline & & $304 \mathrm{mM} \mathrm{Cl}^{-}$ & 5.5 \\
\hline & \multirow{2}{*}{$\begin{array}{l}\text { Product composition } \\
\text { selection } \\
\text { (High concentration) }\end{array}$} & $497 \mathrm{mM} \mathrm{Cl}^{-}$ & 5.9 \\
\hline & & $995 \mathrm{mM} \mathrm{Cl}^{-}$ & 2.9 \\
\hline \multirow{5}{*}{ EDBM } & \multirow{3}{*}{$\begin{array}{c}\text { Acid selection } \\
\text { (Low concentration) }\end{array}$} & $50 \mathrm{mM} \mathrm{HCl}$ & 1.3 \\
\hline & & $50 \mathrm{mM} \mathrm{H}_{2} \mathrm{SO}_{4}$ & 1.3 \\
\hline & & $25 \mathrm{mM} \mathrm{HCl}^{2} 25 \mathrm{mM} \mathrm{H}_{2} \mathrm{SO}_{4}$ & 1.5 \\
\hline & \multirow{2}{*}{ Experiments from SED } & $100 \mathrm{mM} \mathrm{HCl}$ & 4.2 \\
\hline & & $100 \mathrm{mM} \mathrm{H}_{2} \mathrm{SO}_{4}$ & 5.8 \\
\hline
\end{tabular}

4 As it reported in Table 5, working at low feed concentrations implied low Ec values, although 5 also low final concentrations in the product and the brine tank were achieved (Table 4). For

6 the SED experiment carried out with the medium and high concentrations effluents, an Ec 7 average of $6.4 \mathrm{kWh} / \mathrm{kg}$ product obtained was calculated. For the EDBM experiments, lower 8 energy consumption values $(\sim 1.4 \mathrm{kWh} / \mathrm{kg} \mathrm{NaOH})$ were also calculated working with the 9 lower initial concentrations. However, higher Ec values (around $5 \mathrm{kWh} / \mathrm{kg} \mathrm{NaOH}$ ) were 10 estimated when the obtained SED streams were treated by EDBM. These values are in 11 accordance with the Ec values for similar systems found in the scientific literature, such as 3 $12 \mathrm{kWh} / \mathrm{kg} \mathrm{NaOH}[31]$ or $2.6 \mathrm{kWh} / \mathrm{kg} \mathrm{NaOH}[27]$. 


\section{5. CONCLUSIONS}

2 This study demonstrated that it was possible to valorize chemical industry process brines

3 (containing $\mathrm{NaCl}$ and $\mathrm{Na}_{2} \mathrm{SO}_{4}$ ) by means of a combination of two current-driven ion4 exchange membrane technologies: SED and EDBM.

5 First of all, chloride and sulfate ions were separated by SED reaching purities of more than 90

$6 \% \mathrm{SO}_{4}{ }^{2-}$ in the divalent-rich stream and about $90 \% \mathrm{Cl}^{-}$in the monovalent-rich stream.

7 Different initial electrolytes and several concentration values were tested in order to reach the maximum separation efficiency, and the optimal result was to use an initial $\mathrm{NaCl}$ solution in the brine and product compartments with a double concentration than the brine feed. EDBM is a suitable process to produce base and acid from the SED monovalent-rich and divalent-rich stream separated by SED. Pure $\mathrm{NaOH}$ were produced in both cases, whereas $\mathrm{HCl}$-rich $(87 \%)$ and $\mathrm{H}_{2} \mathrm{SO}_{4}$-rich (93\%) acids were obtained when the SED monovalent-rich stream or the SED divalent-rich stream were used as EDBM feed, respectively. Finally, Ec evolution curves were calculated for each experiment and it is important to point out that it is better to work by SED or EDBM until the production (brine and product or base and acid streams, respectively) become almost constant, because in that point the Ec increased drastically.

\section{Acknowledgements}

This research received support by the ZERO-DISCHARGE project (CTQ2011-26799) and the Waste2Product (CTM2014-57302-R) financed by the Spanish Ministry MINECO and the Catalan Government (Project Ref. SGR2014-50-SETRI), Spain. The work of Mònica Reig was supported by the Spanish Ministry (MINECO) within the scope of the grant BES-2012051914. We would also like to acknowledge to C. Monserrat and A. Lara for their contribution to the project.

\section{REFERENCES}

28 [1] R. Bond, S. Veerapaneni, Zero Liquid Discharge for Inland Desalination, Awwa Research Foundation, Kansas City, 2007.

[2] S. Dolnicar, A.I. Schäfer, Desalinated versus recycled water: public perceptions and profiles of the accepters., J. Environ. Manage. 90 (2009) 888-900. 
1 [3] L.F. Greenlee, D.F. Lawler, B.D. Freeman, B. Marrot, P. Moulin, Reverse osmosis desalination: water sources, technology, and today's challenges., Water Res. 43 (2009) 2317-48.

[4] A. Pérez-González, A.M. Urtiaga, R. Ibáñez, I. Ortiz, State of the art and review on the treatment technologies of water reverse osmosis concentrates, Water Res. 46 (2012) $267-283$.

[5] A. Subramani, J.G. Jacangelo, Treatment technologies for reverse osmosis concentrate volume minimization: A review, Sep. Purif. Technol. 122 (2014) 472-489.

[6] B. Van Der Bruggen, L. Lejon, C. Vandecasteele, Reuse, treatment, and discharge of the concentrate of pressure-driven membrane processes, Environ. Sci. Technol. 37 (2003) 3733-3738.

[7] OECD, Managing Water for All: An OECD Perspective on Pricing and Financing, Paris, France, 2009.

[8] SPIRE, Sustainable Process Industry through Resource and Energy efficiency, Road Map, (2013).

[9] A. Dabrowski, Z. Hubicki, P. Podkościelny, E. Robens, Selective removal of the heavy metal ions from waters and industrial wastewaters by ion-exchange method., Chemosphere. 56 (2004) 91-106.

[10] V.S. Soldatov, V.M. Zelenkovskii, L.A. Orlovskaya, Sorption of bivalent ions by a fibrous chelating ion exchanger and the structure of sorption complexes, React. Funct. Polym. 71 (2011) 49-61.

[11] Y. Yoon, R. Lueptow, Removal of organic contaminants by RO and NF membranes, J. Memb. Sci. 261 (2005) 76-86.

[12] H. Strathmann, Electrodialysis, a mature technology with a multitude of new applications, Desalination. 264 (2010) 268-288.

[13] Y. Tanaka, Ion-exchange membrane electrodialysis program and its application to multi-stage continuous saline water desalination, Desalination. 301 (2012) 10-25.

[14] Y. Tanaka, M. Reig, S. Casas, C. Aladjem, J.L. Cortina, Computer simulation of ionexchange membrane electrodialysis for salt concentration and reduction of $\mathrm{RO}$ discharged brine for salt production and marine environment conservation, Desalination. 367 (2015) 76-89. 
1 [15] Y. Tanaka, R. Ehara, S. Itoi, T. Goto, Ion-exchange membrane electrodialytic salt production using brine discharged from a reverse osmosis seawater desalination plant, J. Memb. Sci. 222 (2003) 71-86.

[16] Y. Tanaka, A computer simulation of feed and bleed ion exchange membrane electrodialysis for desalination of saline water, Desalination. 254 (2010) 99-107.

[17] F. Valero, R. Arbós, Desalination of brackish river water using Electrodialysis Reversal (EDR): Control of the THMs formation in the Barcelona (NE Spain) area, Desalination. 253 (2010) 170-174.

[18] D.W. Houldsworth, Demineralization of whey by means of ion exchange and electrodialysis, Int. J. Dairy Technol. 33 (1980) 45-51.

[19] E. Vera, J. Sandeaux, F. Persin, G. Pourcelly, M. Dornier, J. Ruales, Deacidification of passion fruit juice by electrodialysis with bipolar membrane after different pretreatments, J. Food Eng. 90 (2009) 67-73.

[20] Y. Zhang, S. Paepen, L. Pinoy, B. Meesschaert, B. Van der Bruggen, Selectrodialysis: Fractionation of divalent ions from monovalent ions in a novel electrodialysis stack, Sep. Purif. Technol. 88 (2012) 191-201.

[21] T. Xu, Electrodialysis processes with bipolar membranes (EDBM) in environmental protection - a review, Resour. Conserv. Recycl. 37 (2002) 1-22.

[22] G. Pourcelly, Electrodialysis with Bipolar Membranes: Principles, Optimization, and Applications, Russ. J. Electrochem. 38 (2002) 919-926.

[23] P. Pinacci, M. Radaelli, Recovery of citric acid from fermentation broths by electrodialysis with bipolar membranes, Desalination. 148 (2002) 177-179.

[24] K. Zhang, M. Wang, D. Wang, C. Gao, The energy-saving production of tartaric acid using ion exchange resin-filling bipolar membrane electrodialysis, J. Memb. Sci. 341 (2009) 246-251.

[25] C. Huang, T. Xu, Y. Zhang, Y. Xue, G. Chen, Application of electrodialysis to the production of organic acids: State-of-the-art and recent developments, J. Memb. Sci. 288 (2007) 1-12.

[26] V. Mavrov, H. Chmiel, B. Heitele, F. Rögener, Desalination of surface water to industrial water with lower impact on the environment: Part 4: Treatment of effluents from water desalination stages for reuse and balance of the new technological concept 
for water desalination, Desalination. 124 (1999) 205-216.

[27] M. Reig, S. Casas, O. Gibert, C. Valderrama, J.L. Cortina, Integration of nanofiltration and bipolar electrodialysis for valorization of seawater desalination brines: Production of drinking and waste water treatment chemicals, Desalination. 382 (2016) 13-20.

[28] B. Van Der Bruggen, a Koninckx, C. Vandecasteele, Separation of monovalent and divalent ions from aqueous solution by electrodialysis and nanofiltration., Water Res. 38 (2004) 1347-53.

[29] Y. Tanaka, H. Uchino, S. Matsuda, Y. Sato, Batch ion-exchange membrane electrodialysis of mother liquid discharged from a salt-manufacturing process. Experiment and simulation, Sep. Purif. Technol. 156 (2015) 276-287.

[30] M. Reig, S. Casas, C. Aladjem, C. Valderrama, O. Gibert, F. Valero, et al., Concentration of $\mathrm{NaCl}$ from seawater reverse osmosis brines for the chlor-alkali industry by electrodialysis, Desalination. 342 (2014) 107-117.

[31] W. Ye, J. Huang, J. Lin, X. Zhang, J. Shen, P. Luis, et al., Environmental evaluation of bipolar membrane electrodialysis for $\mathrm{NaOH}$ production from wastewater: conditioning $\mathrm{NaOH}$ as a CO2 absorbent, Sep. Purif. Technol. 144 (2015) 206-214. 